\section{ekf}

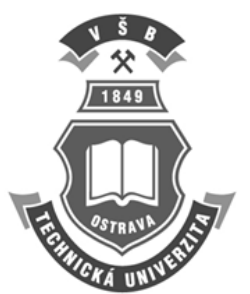

\title{
Convergence in the EU related to the Maastricht criteria
}

\author{
Magdaléna DRASTICHOVÁ*
}

Department of Regional and Environmental Economics, Faculty of Economics, Vঙ̌B - Technical University of Ostrava, Sokolská 33, 70121 Ostrava, Czech Republic.

\begin{abstract}
Regarding the entry into the euro area, the convergence of the EU economies can be monitored in several dimensions. One of them is the convergence represented by the Maastricht criteria, which are the only official conditions of joining the euro area for the EU countries. The aim of this paper is to detect the development of convergence related to these criteria in the EU and to draw mutual relations between the convergence criteria and the impact of compliance with these criteria on other kinds of convergence. Subsequently, some impacts of meeting these criteria on the economic growth of the EU economies joining the euro area are derived. Accordingly, some asymmetric transmission channels related to the convergence indicators embodied in the Maastricht criteria can work in the monetary union and can have impacts on the economic growth in the euro area. Attention is paid to the impact of convergence in terms of compliance with the Maastricht criteria in a broader meaning and in interaction with convergence according to other concepts. Moreover, the most recent economic crisis has had a significant impact on the development of convergence criteria in the EU and its countries.
\end{abstract}

\section{Keywords}

Convergence, economic growth, fiscal discipline, real exchange rate, the Maastricht criteria.

JEL classification: E52, E62, F15

*magdalena.drastichova@vsb.cz 


\title{
Convergence in the EU related to the Maastricht criteria
}

\author{
Magdaléna DRASTICHOVÁ
}

\section{Introduction}

The Maastricht criteria are the only official conditions of membership of the euro area. They were introduced in Article 109j of the Treaty establishing the European Community as amended by the Maastricht Treaty (signed in 1992) and specified in the Protocol on the Convergence Criteria, which refers to that article. Recently, the criteria have been based on Article 140 of the Treaty on the Functioning of the European Union as amended by the Lisbon Treaty (signed in 2007). In this paper, the convergence of the macroeconomic indicators covered by these criteria is examined. This is carried out with regard to the long-term sustainability of their fulfilment assuming the membership of the EU economies in the euro area. The indicators of the Maastricht criteria are not monitored as explicitly defined in the primary law. The basic classification of convergence indicators according to these criteria is used and in addition some alternative macroeconomic indicators referring to the basic classification are examined as well. Thus, the fields of interest are the convergence of inflation rates and interest rates, the development of exchange rates as well as fiscal discipline in EU economies in relation to the participation in the single currency area (monetary union).

The aim of this paper is to detect the development of convergence related to these criteria in the EU and to draw mutual relations between the convergence criteria and the impact of compliance with these criteria on other kinds of convergence. Some impacts of meeting these criteria on the economic growth of the EU economies are derived as well. Relevant aspects are thereby derived in consideration of the membership of the EU economies in the euro area, where the autonomous monetary and exchange rate policy cannot be used. This can have significant impacts on the macroeconomic development. The paper is divided into four sections. After the introduction, the nominal and real convergence and the interconnections of the Maastricht criteria are introduced in the second section. The third section is devoted to the description of the methodology. The fourth one is divided according to the particular areas of nominal convergence as defined by the basic classification of the Maastricht criteria. However, the significant aspects of convergence are analysed in this section, not the exact fulfilment of the Maastricht criteria. One sub-section is devoted to the impacts of convergence represented by the Maastricht criteria on economic growth, which is completed with some effects of the Maastricht criteria on other kinds of convergence. The effects of the economic crisis on the development of the convergence criteria are described by examining particular convergence indicators.

\section{Definitions and interconnections of the analysed convergence indicators}

Before the analysis it is necessary to introduce basic definitions of the relevant types of convergence as well as to describe their interconnections.

\subsection{Definition of nominal and real convergence and the Maastricht criteria}

At the beginning, it is appropriate to define what may be understood as nominal convergence at the macroeconomic level. Attention is paid to the convergence of the EU economies with regard to their participation in the euro area. In a broad conception, nominal convergence can be regarded as the convergence of nominal variables, such as prices, inflation rates, interest rates, nominal wages, pensions, etc. In a narrow conception, the convergence of comparable price levels (CPL) expressed by the indicator of Eurostat can be considered as nominal convergence at the macroeconomic level. The most comprehensive definition of nominal convergence is based on using the nominal GDP per capita of economies, in which the GDP per capita is recalculated by the market exchange rate to the euro. The convergence of the nominal GDP per capita (in euros) among the EU economies leads to a reduction in the gap between the market exchange rate and the rate of purchasing power parity (PPP) and thus to nominal convergence defined by the nominal GDP per capita (Žd'árek, 2006). Nominal convergence was understood by Kowalski (2003) as the convergence of certain macroeconomic indicators to the levels ensuring macroeconomic stability in the economic integration group. In accordance with this concept, the nominal convergence within the EU is particularly associated with the fulfilment of the Maastricht criteria, which are part of the primary law. They are 
the only official conditions that the EU countries are required to meet in order to join the euro area. Their purpose is to ensure monetary or macroeconomic stability in the euro area, which should create a favourable environment for long-term economic growth. They contain three monetary and two fiscal criteria.

The first monetary criterion is related to the price developments, i.e. the similarity of inflation rates. The treaty in Article 140(1) requires the achievement of a high degree of price stability (the Treaty on the Functioning of the European Union as amended by the Lisbon Treaty, 2007). The second one concerns the exchange rate developments, i.e. achieving exchange rate stability, which should demonstrate the country's ability to exist without its own monetary policy in a low-inflation environment. Participation in the ERM II mechanism, which is associated with this criterion, ought to help ensure that member states outside the euro area lead their policies to stability or to boost convergence in order to participate in the single currency area. Regarding the third monetary criterion, Article 140(1) of the treaty requires the durability of convergence achieved by the member state with a derogation. This is related to the long-term interest rate developments. Regarding the fiscal criteria, Article 140(1) of the treaty requires the sustainability of the government financial position. In terms of that, a government budgetary position without a deficit that is excessive has to be achieved as determined in accordance with Article 126(6) (the Treaty on the Functioning of the European Union as amended by the Lisbon Treaty, 2007).

Accordingly, nominal convergence is understood as compliance with the Maastricht convergence criteria, i.e. convergence of the values of the monetary criteria and not exceeding the threshold values established by the fiscal criteria. By two monetary criteria, namely the price (inflation) and interest rate criteria, the emphasis is put on achieving low rates of indicators. The price criterion is measured by the average rate of the HICP inflation, whereas the average rate of inflation, observed over a period of one year before the examination, is not more than 1.5 percentage points (p.p.) above the rate of the three bestperforming member states. The interest rate criterion pursues the development of the long-term nominal interest rate, which will be measured on the basis of the long-term government bonds or comparable securities, taking into account the differences in the national definitions. It requires that the average nominal long-term interest rate does not exceed by more than 2 p.p. that of, at most, the three bestperforming member states in terms of price stability over a period of one year before the examination (Article 140(1) of the Lisbon Treaty). The third monetary criterion, namely the exchange rate criteri- on, requires the observance of the normal fluctuation margins provided for by the exchange rate mechanism (ERM II), ${ }^{1}$ for at least two years before the examination, without devaluation against the euro and without severe tensions. Regarding the fiscal criteria, the ratio of the planned or actual government deficit and government debt to GDP should not exceed the reference value (defined in the protocol on the excessive deficit procedure as $3 \%$ and $60 \%$ of the GDP). However, as indicated earlier, the criteria are analysed in the broader context of convergence, not only in terms of defined reference values and but also in terms of alternative indicators.

Real convergence in macroeconomic terms is the process of less-developed countries catching up with developed ones or approaching their real parameters and conditions (Šikulová, 2006). There is no welldefined set of indicators of real convergence. It is expressed mainly via the real GDP per capita or GDP per capita in terms of purchasing power parity (PPP). The concept of $\beta$ convergence is widely used to examine the real convergence of economies. This concept is based on the assumption that the poor economies, i.e. those at a lower initial level of the real GDP per capita, are likely to grow faster than the rich ones, i.e. those at a higher level (Barro and Sala-iMartin, 2004). Together with the process of real $\beta$ convergence, the price level of the converging economy grows too and nominal (price) convergence takes place. It is necessary to stress this process in the EU, because the EU consists of countries at various economic and price levels. Generally, the new member states, which are countries at lower economic and price levels, should converge with the higher levels, i.e. the levels of more developed economies. This can have impacts on the fulfilment of the Maastricht criteria as well as on the participation of such countries in the common monetary union.

\subsection{Basic interconnections of the Maastricht criteria}

There are interconnections of three monetary criteria. Price in/stability affects the exchange rate and conversely the exchange rate affects the price in/stability.

\footnotetext{
${ }^{1}$ In the treaty (Article 140 (1)), the exchange rate mechanism of the European Monetary System is mentioned. However, in terms of the application of the treaty provisions, recently the Exchange Rate Mechanism (ERM II) has been used to assess the fulfilment of the exchange rate criterion. It was set up on 1 January 1999 as a successor to the ERM to ensure that the exchange rate fluctuations between the euro and other EU currencies do not disrupt the economic stability within the single market and to help non euro-area countries prepare for participation in the euro area.
} 
A link exists between the inflation rate and the interest rate, between the interest rate and the exchange rate and between the inflation rate and the exchange rate. Convergence of interest rates is emphasized as a factor of monetary stability in the euro area, which should lead to roughly similar credit terms. The existence of interest rate differentials can lead to speculative capital movements and pressure on the appreciation or depreciation of currencies. The fulfilment of the price and exchange rate criteria at the same time is inconsistent with the assumption that the convergence of price levels of economies at the lower economic and price levels is taking place and these economies are catching up with the economies at higher levels. By this development, the real exchange rate (RER), which is the nominal exchange rate adjusted according to the changes in the relative purchasing power of currencies, i.e. inflation rates, appreciates. It is possible to use the exchange rate or price channel of the real appreciation in terms of the catching up of the CPL. However, the performance of these two criteria excludes both channels simultaneously by limiting the inflation rate and the exchange rate movements. The Maastricht criteria also include two fiscal criteria, setting maximum levels for the ratios of government deficit and debt to the GDP. High deficit and debt levels lead to an increase in interest rates, to speculative capital movements and thus to pressure on the exchange rate. Depending on the monetary regime of a country, it can be reflected in the inflation rate or in the exchange rate in various proportions. This is also general evidence of the fact that significant relations exist between the inflation and the exchange rate, which are reflected in the RER development.

In summary, it can be said that stable inflation and exchange rates, the convergence of interest rates and fiscal stability create a favourable environment for long-term economic growth. However, compliance with the criteria at the same time may be inconsistent and affect the convergence of the EU economies in other specified dimensions. An additional problem with the framework of criteria cannot be left unmentioned, because the framework alone can be doubtful. The three best-performing member states in terms of price stability, which are included to assess the price and interest rate criteria, are chosen from the EU, not only from the euro area members. Therefore, it is possible that the criteria will not reflect the situation in the euro area if the best-performing countries are predominantly the non-euro area countries.

\section{The background of the methodology}

The indicators that are monitored and examined in this paper were chosen according to the basic framework of the Maastricht convergence criteria. It follows that the framework of these criteria determines the basic structure of the paper. However, the indicators are chosen in accordance with the purpose of the analysis, which is the detection of development and the drawing of the relations between the examined areas of convergence and the impacts on other kinds of convergence in the EU. This means that the analysis of the concrete criteria is sometimes completed with additional indicators (monitoring of interests rates) or only alternative indicators are used (monitoring of exchange rates). In addition, the statistical indicators, particularly the standard deviations (SD), variances and coefficients of variation (CVs), are used to detect the convergence of two criteria. To examine the inflation rates' convergence the SDs are calculated and to examine the interest rates' convergence the variances are calculated. In addition, the SDs and CVs available in Eurostat's statistics are included in the analysis. The calculation of standard deviations of inflation rates is based on the sum of squares of the average HICP inflation rates' differences between countries and the benchmark (the EU and the euro area), divided by the adequate number of countries and calculating the square root.

The real exchange rate (RER) indicators were chosen for analysis because the RER is an indicator of both nominal and real convergence, so their interrelations can be subsequently pointed out. Frait and Komarek (2001) argued that economic convergence can be analysed using the real exchange rate. The variability of RERs is a key characteristic that is observable in historical data and RER changes are easily measurable. To examine the exchange rate development in the EU countries, it was chosen to monitor the real exchange rate (RER) development instead of the nominal exchange rates. As mentioned above, the development of RERs can better help detect convergence in more economic areas as well as the relations between convergence indicators. Within the EU, Eurostat and the ECB monitor the competitiveness indices, i.e. relative price and cost indicators, which are the indicators of the real effective exchange rate (REER) relative to its major trading partners in international markets. The REER indicator corresponds to the nominal effective exchange rate (NEER) deflated by the nominal unit labour costs in the total economy, consumer price indices (CPI/HICP) or other price indices. The NEER only measures changes in the value of the country's currency relative to the currencies of its major trading partners. A rise in the index means strengthening of the currency. Changes in cost and price competitiveness depend not only on exchange rate movements but also on cost and price trends. Therefore, a rise in the REER index means a loss of competitiveness. 
Fiscal criteria are monitored in order to detect the level of fiscal discipline that has been achieved in the EU countries because it is interrelated with other areas of economic convergence. To monitor the fiscal criteria, the indicators of the general government budget and debt in the form of a percentage of the GDP as in the original Maastricht criteria are used. The threshold values of the criteria, as specified in the protocol on the excessive deficit procedure annexed to the treaties, are taken into account. However, the assessment of whether these criteria are met according to the threshold values is complicated by the fact that the majority of the EU countries have exceeded these values due to the most recent financial and economic crisis. In addition, the examination of the fiscal criteria is completed with the monitoring of the external balance, in which the current account of the balance of payments is used as an indicator. The reason for this is the existence of a significant interrelation between the fiscal discipline and the external balance of countries.

Following the detailed monitoring and analysis of the above-mentioned indicators in the EU countries, conclusions are drawn about the relations of such convergence with other areas of convergence and potential impacts on economic growth. Thereby, the focus is especially placed on those aspects of convergence and impacts on economic growth that are related to participation in the monetary union, i.e. the euro area. In doing so, knowledge of asymmetric transmission channels is used (Mongelli, 2008).

\section{Development of the convergence defined by the Maastricht criteria}

The following section contains the analysis of convergence defined by the Maastricht criteria. It starts with the convergence of inflation rates in the EU and the euro area. Then the development of exchange rates is examined. Third subsection is focused on the convergence of interest rates in the EU and the euro area and the fourth one on fiscal criteria and their importance to convergence in the EU and the euro area. In the fourth subsection the impacts of the Maastricht convergence criteria on the economic growth are introduced.

\subsection{Convergence of inflation rates in the $\mathrm{EU}$ and the euro area}

The convergence of inflation rates is linked to the fulfilment of the price Maastricht criterion but it is also one of the more recent criteria of the optimum currency area (OCA) theory. Differences in inflation rates lead to a loss of competitiveness in economies with high inflation rates, which raises the need for mechanisms of adaptation in the monetary union. Although the variance of inflation rates in the euro area during certain periods has been reduced, the inflation differentials across countries have persisted for long periods. The inflation in many EU countries shows significant persistence, and many countries have inflation rates above the EU or euro area average over the long term. Persistent differentials are a reflection of structural rigidities as well. In most economies, it takes longer to adjust the formation of prices and wages according to the changing conditions on the labour and product markets. Figure 1 indicates a decrease in the average inflation rates measured by the Harmonised Index of Consumer Prices (HICP) between the period 1997-2003 and the period 2004-2010, especially in the new member states. There has been an increase in some older member states, ${ }^{2}$ such as the United Kingdom (UK), Luxembourg, Belgium, Germany, Austria, France and Sweden. Regarding the new member states, the inflation rates have increased only in Latvia and Lithuania. However, the second period includes the period of the global economic crisis, when in 2009 a significant decline in inflation rates occurred.

It is appropriate to examine the SDs of changes in the HICP index in the EU and the euro area (see the methodology of calculation in Section 3). They are depicted in Figure 2, which shows that the SD in the EU increased after the accession of new member states, i.e. in 2005 and to a lesser extent in 2006. The increase was not detected in 2004 because the new member states had not yet been included in the calculation of the SD indicator. The SDs also significantly increased in 2007 and 2008, which are the years immediately before the significant impacts of the economic crisis. The SD indicator decreased in the other monitored years. In the euro area, the SDs significantly increased after its establishment, i.e. in 2000 , then declined with a slight increase in 2005 and more significant increases occurred in 2008 and 2010. The SD increase in the euro area in 2000 can be associated with economies' lower level of effort to continue to maintain very low inflation rates in terms of meeting the Maastricht criteria after the euro area's establishment. The HICP inflation rate increased annually in 2000 for all the euro members at that time. Even though the SD indicator was already growing in the euro area in the late $1990 \mathrm{~s}$, the inflation rates decreased in 1998 and 1999 within more countries that were preparing themselves for euro area membership. On the other hand, the high inflation rates in the Baltic economies, Bulgaria, Romania, Hungary and the Czech Republic in 2008 in combination with their

\footnotetext{
2 The new member states are understood as the group of the EU-10 countries, i.e. the countries that have joined the EU since 2004. The older member states are the remaining EU15 members.
} 


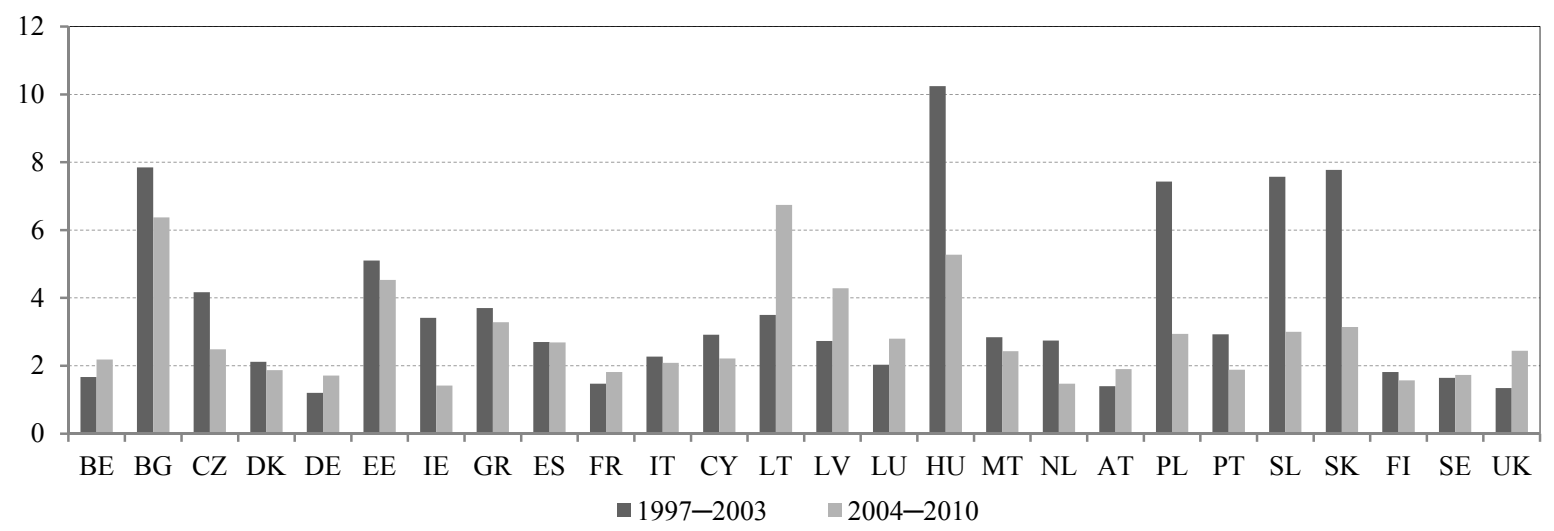

Figure 1 Annual average rate of the HICP change in 26 EU member states: the average of the 1997-2003 and 2004-2010 periods, $\%$

Source: Eurostat (2012), own elaboration

Note: Romania has not been included in Figure 1 for the sake of clarity. In the first reference period, the economy reached the average inflation rate of $53.957 \%$ and in the second one the rate was $7.443 \%$. For Bulgaria, the first average is computed for the period 1998-2003 due to the lack of data for 1997.

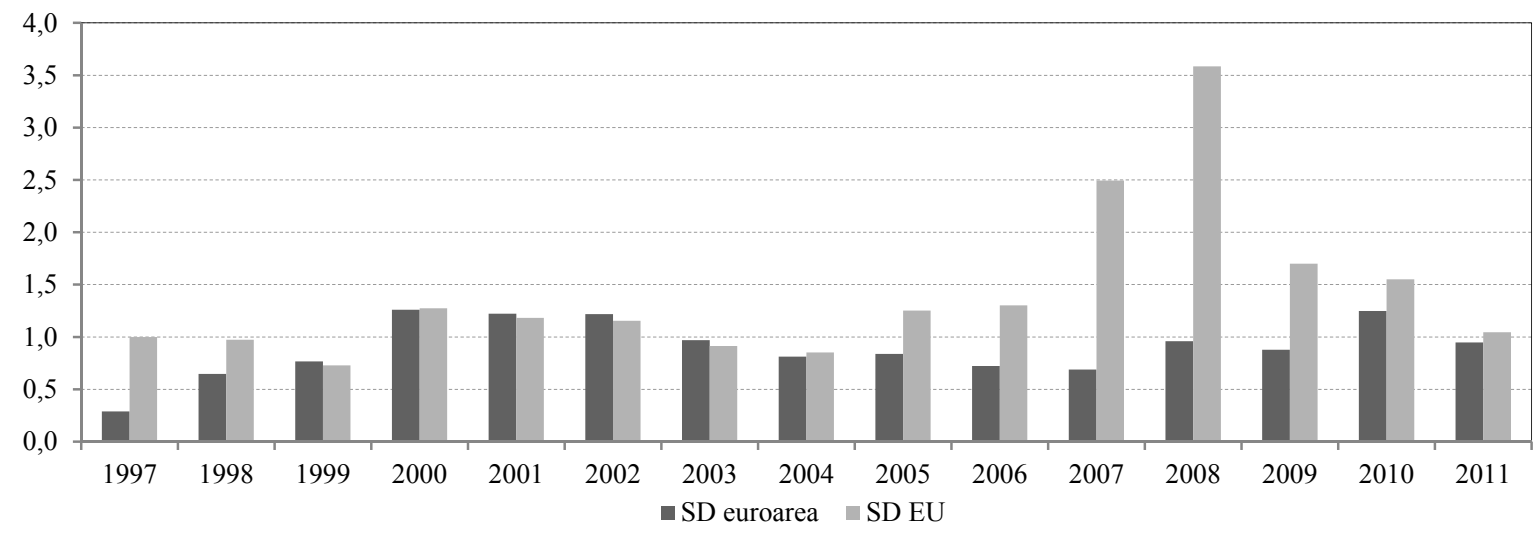

Figure 2 Standard deviations of HICP inflation rates in the EU and the euro area, 1997-2011

Source: Eurostat (2012), own elaboration

Note: In the calculation of the indicator for the EU are included the countries of the EU-15 until 2004, the countries of the EU25 from 2005 to 2006 and the countries of the EU-27 since 2007, i.e. including Bulgaria and Romania. Regarding the euro area, it includes the countries of the EA-11 (EU-15 except the United Kingdom, Denmark, Sweden and Greece) until 2000, the EA-12 from 2001 to 2006 (EA-11 and Greece), EA-13 in 2007 (EA-12 and Slovenia), EA-15 in 2008 (EA-13, Malta and Cyprus), EA-16 from 2009 to 2010 (EA-15 and Slovakia) and EA-17 in 2011 (including Estonia). The same applies to the inclusion of countries' HICP inflation rates in the average HICP rate of the EU and the euro area.

lower levels in several countries, e.g. the Netherlands, Malta and France in 2007 (see also Figure 1), are mainly responsible for the significantly high SDs across the EU in these years. However, in the period just before the crisis, the Baltic economies mainly achieved high growth rates, thus these economies were later hit harder by the crisis. In 2009, the SD indicator decreased in both groups because of the recession and low inflation rates in all the countries of the EU.

Besides the structural rigidities, differences in inflation rates will persist if there are, among others, differences in the price levels between economies. In general, the differences in the CPL between the economies are affected by many factors, such as the shares of the non-tradable sector in the economies, the size of indirect taxes, the speed or costs of arbitrage, the existence of imperfect competition structures, etc., which are the economic factors. Besides the economic factors causing the CPL differences among countries, there are also non-economic ones. Examples of these are the consumer preferences, which reflect the local habits, or consumers' effects (Vintrová and Žd'árek, 2007). In transition economies, there may also be price distortions originating from the former regime. The differences in the CPL may just reflect the convergence to a new equilibrium level of the CPL, i.e. price convergence or nominal convergence in the 
narrow concept, which takes place together with the convergence of the economic level. Then, the changes in prices may also be more significant if the exchange rate channel of the CPL is reduced. Generally, countries with a lower initial economic level, most often measured by the GDP per capita, also have a lower level of the CPL and convergence with the EU average or the values of more advanced economies can occur. Thus, these countries of the EU, which are mainly the new member states or other converging economies, grow on average faster (see e.g. Vintrová and Žd'árek, 2007) in terms of the GDP per capita as well as the CPL.

One factor of the faster CPL growth in the new member states, i.e. the appreciation of a real exchange rate (RER), is the Balassa-Samuelson effect (B-S effect) (Ballassa, 1964; Samuelson, 1964). In converging economies with lower relative labour productivity, i.e. mainly the new member states, rapid growth in labour productivity in the tradable sector has taken place, which has been connected with a differential in productivity growth compared with the non-tradable sector. As a result of wage equalizing between these two sectors, the productivity growth differential translates into an inflation differential. Consequently, the economy reaches a higher overall inflation rate in comparison with an economy with higher initial labour productivity, providing a stable nominal exchange rate and a similar development of tradable goods prices. The alternative possibility is the nominal exchange rate appreciation providing the existence of a floating exchange rate regime. Both channels are reflected in the real exchange rate development, i.e. it leads to RER appreciation and CPL convergence (Benčík, Hajnovič et al., 2005).

It is possible to use the exchange rate or price channel of the real appreciation, but the simultaneous fulfilment of the Maastricht inflation and interest rate criteria can exclude both of these channels of the RER appreciation simultaneously. Therefore, a significant discrepancy and limiting factor of the new member states entering the euro area can result from the simultaneous fulfilment of the official Maastricht criteria of nominal convergence with nominal and real convergence in the narrow concept. The possibilities of parallel compliance with the price and exchange rate criteria and the impacts on the economic and price level as well as on their convergence vary across countries. They depend on the initial economic and price level, monetary regime, above-mentioned factors of the CPL and many others. Figure 1 shows that the price channel plays a significant role in the CPL convergence in Baltic economies as well as in some other new member states. Even if there is the possibility to revaluate a central rate to the euro during the ERM II membership (for example, the rate was revaluated twice in Slovakia), after joining the monetary union the exchange rate channel of catching up with the CPL is completely excluded and the price channel is limited by the monetary policy of the European Central Bank (ECB). Thus, it can lead to the limiting of economic growth in a country with a higher inflation rate or, on the other hand, a country with high inflation rates can lose competitiveness, ultimately having similar impacts. Subsequently, negative impacts on the whole monetary union can occur.

\subsection{Aspects of exchange rate criterion - develop- ment of the real exchange rates}

This section is built on the previous one, but greater attention is paid to the cost factors of the real appreciation. While the previous section was focused on the HICP inflation rates and thus the price channel of the real appreciation, this section is based on the examination of the RER indicators. Although nominal exchange rate movements are reduced due to the ERM II participation and the elimination of these movements with the formation of the monetary union, significant movements in real exchange rates can still occur, so there is a significant relationship between inflation and exchange rate criteria. In the EU economies with a lower initial economic and price level, parallel growth in both indicators and convergence of their values with those of more advanced EU economies take place (Vintrová and Žd'árek, 2007). One of the reasons for this development is the B-S effect, especially in the new member states (see Section 4.1).

However, it is necessary to differentiate between the cost (price) factors and the structural factors of the real appreciation (see Cincibuch and Vavra, 2000). Structural factors push up the inflation of non-tradable items included in the Consumer Price Index (CPI) above the inflation of tradable goods expressed by the Producer's Price Index (PPI). The structural reasons for the real appreciation may be associated with the factors that affect the relative prices of non-tradable goods. Therefore, a country achieves higher growth in the relative prices of non-tradable goods if its labour productivity differential between the tradable and the non-tradable sector is growing faster than in the reference economy (Benčík, Hajnovič et al., 2005). This is the above-mentioned working of the B-S effect (see Section 4.1). The structural factors of the real appreciation do not lead to adverse effects on competitiveness if it is a temporary development in transition economies, resulting from the initially undervalued wages, which have gradually been returning to the equilibrium level (Cincibuch and Vavra, 2000). As described by Cincibuch and Vavra (2000), the RER appreciation and development of the CPL are largely determined by cost and price factors affecting the 
overall competitiveness of the economy. Regarding the price and cost factors of the RER appreciation, the changes in relative labour costs and the resulting inflation differentials affect price and cost competitiveness. Within the EU, these factors are monitored via competitiveness indices (relative price and cost indicators), i.e. the REER indicators relative to the major trading partners in international markets. A rise in the REER index means a loss of competitiveness (see Section 3).

Cincibuch and Vavra (2000) attributed less importance to the structural factors of the real appreciation in comparison with the cost factors. There has been significantly higher growth in unit labour costs in the new member states than in the older ones, which is indicated by the appreciation of the REER based on the ULC (see Figures 3 and 4). This is also reflected in the development of the CPI (HICP) (without Figure). The REER (CPI) development is similar to that of the REER (ULC), with some differences between particular economies. Most of the new member states have recorded significant appreciation of the REER based on the CPI as well as the ULC. This development is also very similar whether the REER relative to the euro area-16 or the REER relative to the EU-27 as a benchmark economy (reference group) is used. In Figures 3 and 4, the entire EU-27 was chosen as a reference group of economies. In Figure 4, a different scale was used in comparison with Figure 3 in order to show unambiguously that the new member states on average recorded strong appreciation of the REER based on the ULC.

In the period 1995-2011, the most significant appreciation of the REER (ULC) was recorded in Romania, Bulgaria and the Czech Republic, followed by five other new member states. All the new member states showed significant real appreciation in the period 1995-2011, whereas the lowest among them was typically Slovenia. In the period 2000-2011, the most significant real appreciation was recorded in Slovakia, followed by Bulgaria and the Czech Republic, and in 2005-2011 again in Bulgaria, followed by Latvia and Slovakia. Six member states experienced real depreciation in the period 1995-2011, i.e. Germany, Austria, Finland, Belgium, France and Sweden (arranged according to the extent of the real depreciation from the highest to the lowest), whereas in the more recent periods, i.e. 2000-2011 and 2005-2011, the UK has dominated in real depreciation. The other older member states showed appreciation of the REER during the whole period 1995-2011, whereas the highest one was typical of Italy, Denmark, Luxembourg and Portugal.

In terms of the REER (CPI), Slovakia dominated in real appreciation in 1995-2011 and it was followed by Lithuania, Bulgaria, the Czech Republic and the group of the other six new member states. Overall, all the new member states recorded real appreciation in this indicator in the whole monitored period, with the lowest one again in Slovenia. At the same time, the most significant depreciation of the REER (CPI) was recorded in Germany, followed by Finland, Austria and the other six older member states. The exceptions were Luxembourg, Portugal, Ireland, Spain, Greece and Italy. In the more recent years, however, the annual real appreciation has not been so significant, i.e. depreciation has been typical of more EU countries (in 2010 and 2011 in Ireland by both indicators, in Greece, Spain and Portugal by REER (ULC) in both years, etc.). Generally, the trend of real appreciation has weakened since 2009 and even intensified in 2010.

The development of both REER indicators represents evidence of the fact that the new member states that recorded real and nominal (price) convergence have also shown significant real appreciation of their currencies. With these countries, the structural factors can still play a role in real appreciation. The trend of real appreciation is a characteristic feature of transitional economies (Cincibuch and Vavra, 2000). However, the separation of structural and costs factors would require a detailed analysis of the price indices' components that cause the real appreciation. ${ }^{3}$ The cost factors of the real appreciation result in possible changes in a country's price or cost competitiveness relative to its EU trading partners. Thus, the growth of indicators can lead to a loss of competitiveness, which is typical not only of the new member states but also of some older members, especially three southern countries and Ireland, with the significant appreciation of the REER indicators in the longer-term period. These trends of appreciation have continued in most recent years in many new and some older members (e.g. Romania, the Czech Republic and Sweden in both indicators in 2010 and 2011 annually) but more older as well as new member states have experienced real depreciation (e.g. Greece, Spain, Portugal, Lithuania, Estonia, Slovakia or Finland in REER (ULC) and then the Netherlands, Denmark, Ireland or Slovenia in both indicators in 2010 and 2011 annually). This can be related to the insufficient growth and generally the negative development in connection with the impacts of the economic crisis, especially in southern economies and Ireland. The single monetary policy applied to 17 economies can further make the situation of countries with significant losses of competitiveness more difficult.

\footnotetext{
${ }^{3}$ This is not the object of the paper because of its macroeconomic focus.
} 


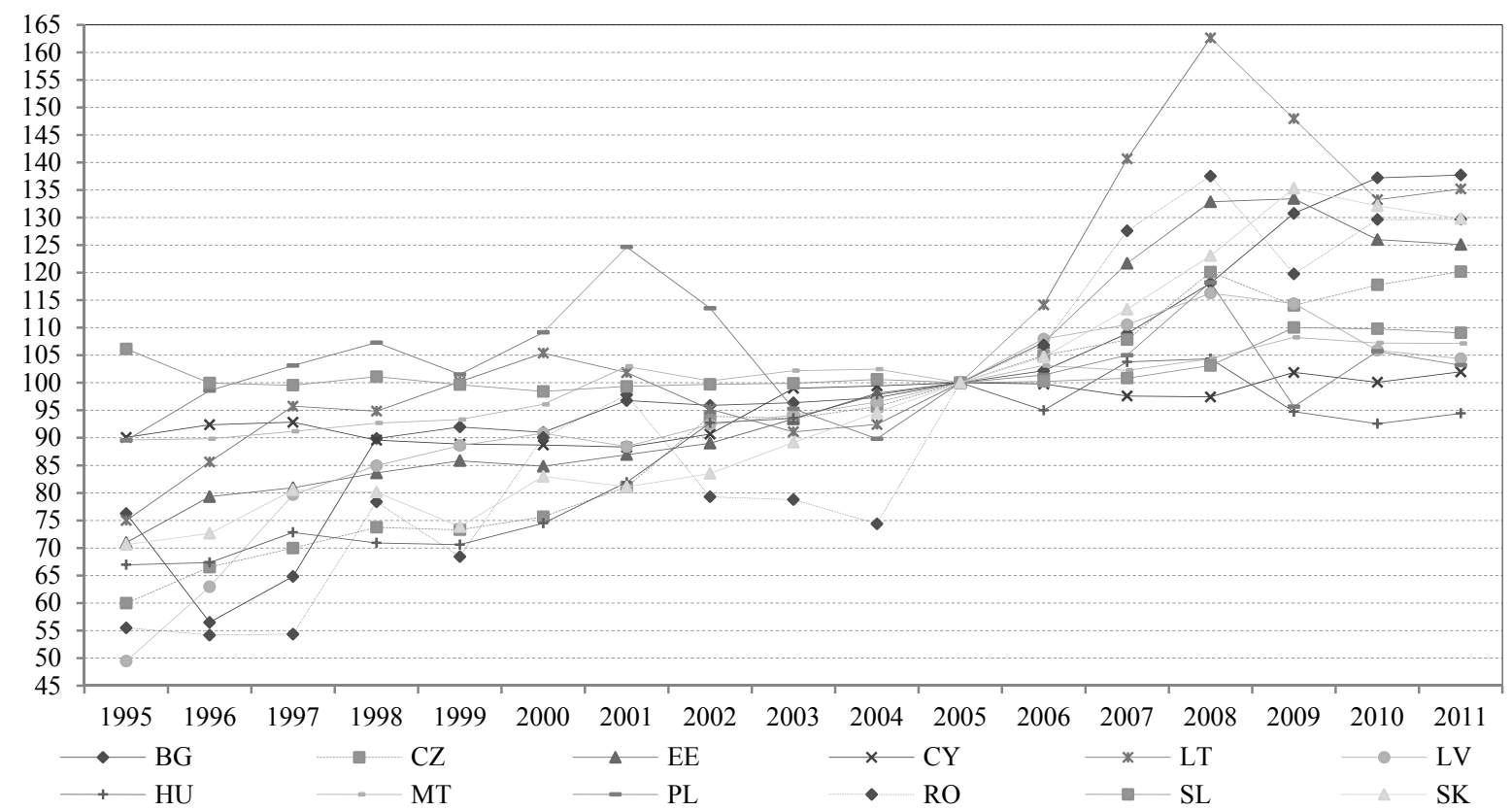

Figure 3 Development of the REER index relative to the EU-27 by new member states (deflator: unit labour costs in the total economy -27 trading partners $),(2005=100), 1995-2011$

Source: Eurostat (2012)

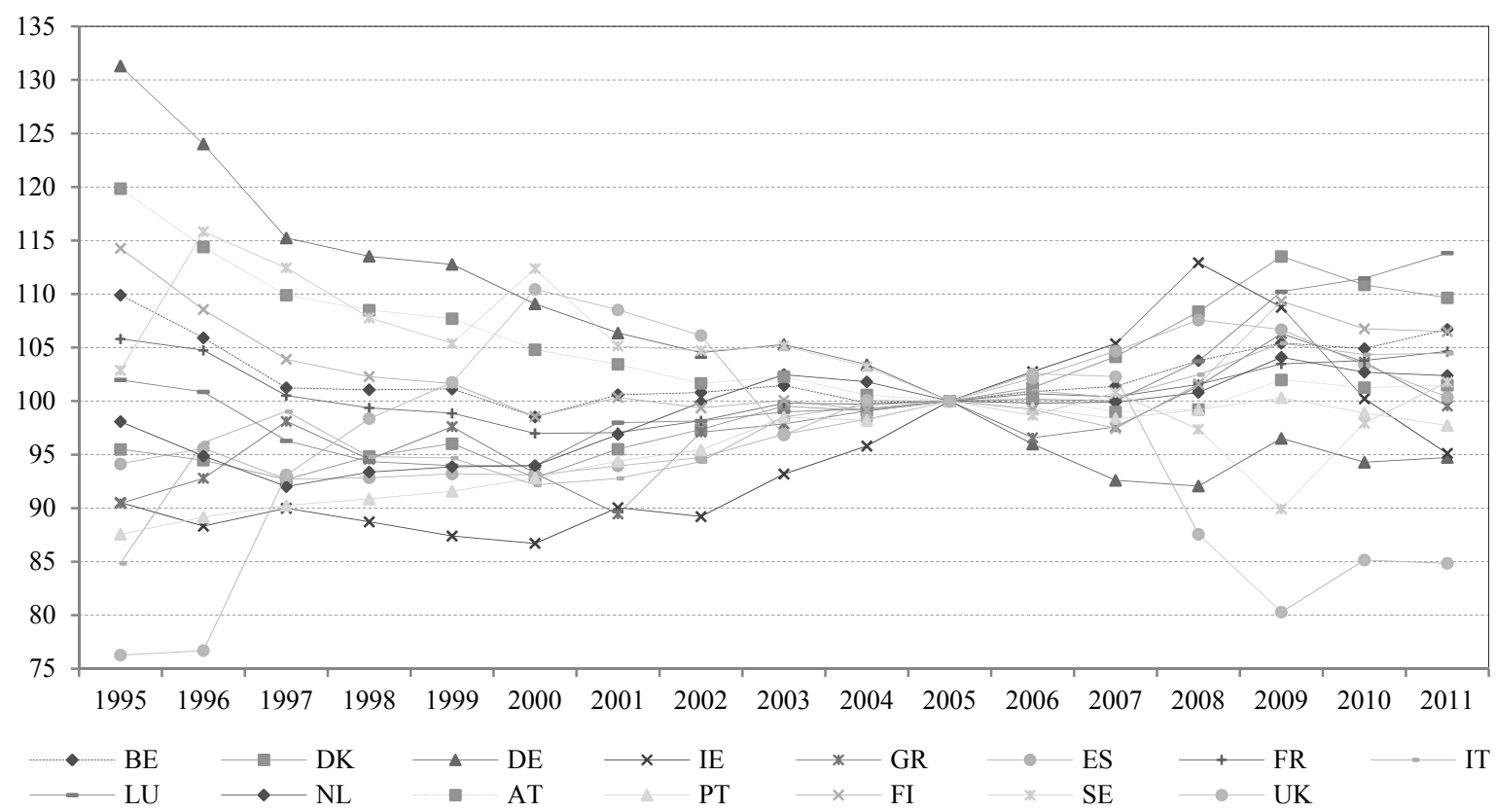

Figure 4 Development of the REER index relative to the EU-27 by new member states (deflator: unit labour costs in the total economy - 27 trading partners), $(2005=100), 1995-2011$

Source: Eurostat (2012)

\subsection{Convergence of interests rates in the $\mathrm{EU}$ and the euro area}

According to the Maastricht criteria, the convergence of interest rates should reflect the durability of convergence. Besides the development of the bond yields, which is used as a convergence criterion within their framework, the development of the standard deviation (SD) and the coefficient of variation (CV) of three kinds of interest rates is examined in this paper. A decline in the SDs and in the CVs of interest rates over time shows an increasing degree of financial market integration in the EU and the euro area. Integration of 
financial markets is the criterion of the OCA theory as well, so a high level of integration should lead to the fact that the benefits from participation in the monetary union exceed the costs associated with it. This should encourage economic growth within the monetary union.

Eurostat provides three sub-indicators: loans to households for house purchases, loans to non-financial corporations for up to one year and loans to nonfinancial corporations for more than one year. For all the sub-indicators, which are included in Table 1, the CVs and the SDs decreased in the period 1996-2012 in the euro area as well as in the EU. This is evidence of the growing integration of financial markets in the EU and the euro area. Generally, the most significant decreases in the SDs and CVs in 1996-2012 took place in the EU-25 (the EU excluding Bulgaria and Romania), which was followed by the group of older EU member states, i.e. the EU-15. On the other hand, the highest level of convergence, i.e. the lowest values of statistical indicators, have been typical of the EU15 or eventually the euro area composed of the initial twelve member states. In the EU-25 and the EU-27, the indicators have shown relatively higher values, but the convergence has taken place faster. In terms of the instruments, the values of the indicators have often shown relatively lower values for loans to enterprises for more than one year in all the groups of EU countries. This represents the relatively higher similarity of these rates across the EU, reflecting their harmonization.

As a result of the financial crisis, the more significant increases occurred in 2009 in all the subindicators and both indicators of convergence in all the groups of the EU and the euro area except for a small decrease in the SD of loans to enterprises for more than one year in the EA-12. ${ }^{4}$ However, an increase took place in this group in the next three following years. Thus, while the values have again been decreasing for most of the indicators in the EU25 (EU-27) in 2010 and 2011, this was not typical of the monitored euro area groups, especially in 2010. The most recent negative phenomenon is the increase in all the indicators in all the groups of countries in 2012. This also confirms the continuing negative impacts of such a negative shock as this economic crisis in the integration group with significantly interlinked economies in which negative effects can shift from one to another. In summary it can be said that externalshocks, such as the most recent economic crisis, can cause significant divergence in interest rates in the integration group of the EU because of the different economic characteristics of its countries. Moreover, the effects can spill over among them and persist for a long time.

Maastricht criterion bond yields are long-term interest rates, used as an interest rate convergence criterion for the European Monetary Union (EMU). ${ }^{5}$ The development in the EU countries is presented in Figure 5. At present, harmonized long-term interest rates are available for 26 of the EU member states.

\footnotetext{
${ }^{4}$ Eurostat overall monitors the euro area as it was extended, the EA-12, EA-15, EU-15, EU-25 and EU-27. In Table 1, data for the euro area and the EU-25 are included.

5 The criterion is related to interest rates for long-term government bonds denominated in national currencies. According to the selection guidelines, data should be based on central government bond yields on the secondary market, gross of tax, with a residual maturity of around 10 years.
}

Table 1 The coefficient of variation (CV) and standard deviation (SD) of interest rates in the EU-25 and the euro area (EA) using three partial indicators: loans to households (HL), non-financial corporations up to one year $(\mathrm{CL}<1)$ and non-financial corporations over one year (CL > 1)

\begin{tabular}{|c|c|c|c|c|c|c|c|c|c|c|c|c|}
\hline Rok & $\begin{array}{c}C V \\
E A \\
(H L) \\
\end{array}$ & $\begin{array}{c}C V \\
E U 25 \\
(H L) \\
\end{array}$ & $\begin{array}{c}C V \\
E A \\
C L<1 \\
\end{array}$ & $\begin{array}{c}C V \\
E U 25 \\
C L<1\end{array}$ & $\begin{array}{c}C V \\
E A \\
C L>1\end{array}$ & $\begin{array}{c}C V \\
E U 25 \\
C L>1\end{array}$ & $\begin{array}{c}S D \\
E A(H L)\end{array}$ & $\begin{array}{c}S D \\
E U 25 \\
(H L) \\
\end{array}$ & $\begin{array}{c}S D \\
E A \\
C L<1 \\
\end{array}$ & $\begin{array}{c}S D \\
E U 25 \\
C L<1\end{array}$ & $\begin{array}{c}S D \\
E A \\
C L>1 \\
\end{array}$ & $\begin{array}{c}S D \\
E U 25 \\
C L>1\end{array}$ \\
\hline 1996 & 28.3 & 61.5 & 39.3 & 62.4 & 28.0 & 61.5 & 2.461 & 6.810 & 2.777 & 6.957 & 2.013 & 6.993 \\
\hline 2000 & 12.6 & 41.4 & 8.3 & 45.1 & 15.7 & 46.6 & 0.839 & 3.616 & 0.484 & 3.906 & 0.939 & 4.037 \\
\hline 2007 & 10.8 & 24.5 & 10.6 & 21.7 & 8.5 & 23.3 & 0.545 & 1.365 & 0.598 & 1.308 & 0.440 & 1.334 \\
\hline 2008 & 12.4 & 25.0 & 10.2 & 20.1 & 8.5 & 22.3 & 0.664 & 1.491 & 0.626 & 1.320 & 0.481 & 1.381 \\
\hline 2009 & 21.5 & 43.9 & 28.5 & 50.4 & 16.8 & 47.6 & 0.911 & 2.303 & 1.185 & 2.626 & 0.670 & 2.443 \\
\hline 2010 & 29.3 & 44.7 & 33.9 & 41.3 & 21.5 & 32.9 & 1.059 & 1.934 & 1.274 & 1.802 & 0.756 & 1.352 \\
\hline 2011 & 24.8 & 40.2 & 33.7 & 35.6 & 20.6 & 30.9 & 0.916 & 1.704 & 1.424 & 1.596 & 0.810 & 1.333 \\
\hline 2012 & 27.4 & 44.6 & 42.3 & 44.6 & 25.4 & 39.3 & 0.961 & 1.803 & 1.704 & 1.892 & 0.950 & 1.624 \\
\hline
\end{tabular}

Source: Eurostat (2013)

Note: In Table 1, the euro area (EA) represents the EA11-2000, EA12-2006, EA13-2007, EA15-2008, EA16-2010 and EA17, where the final year of composition is mentioned. As the EU representative, the EU-25 (without Bulgaria and Romania) was chosen as for the EU-27 data are available only since 2007. 


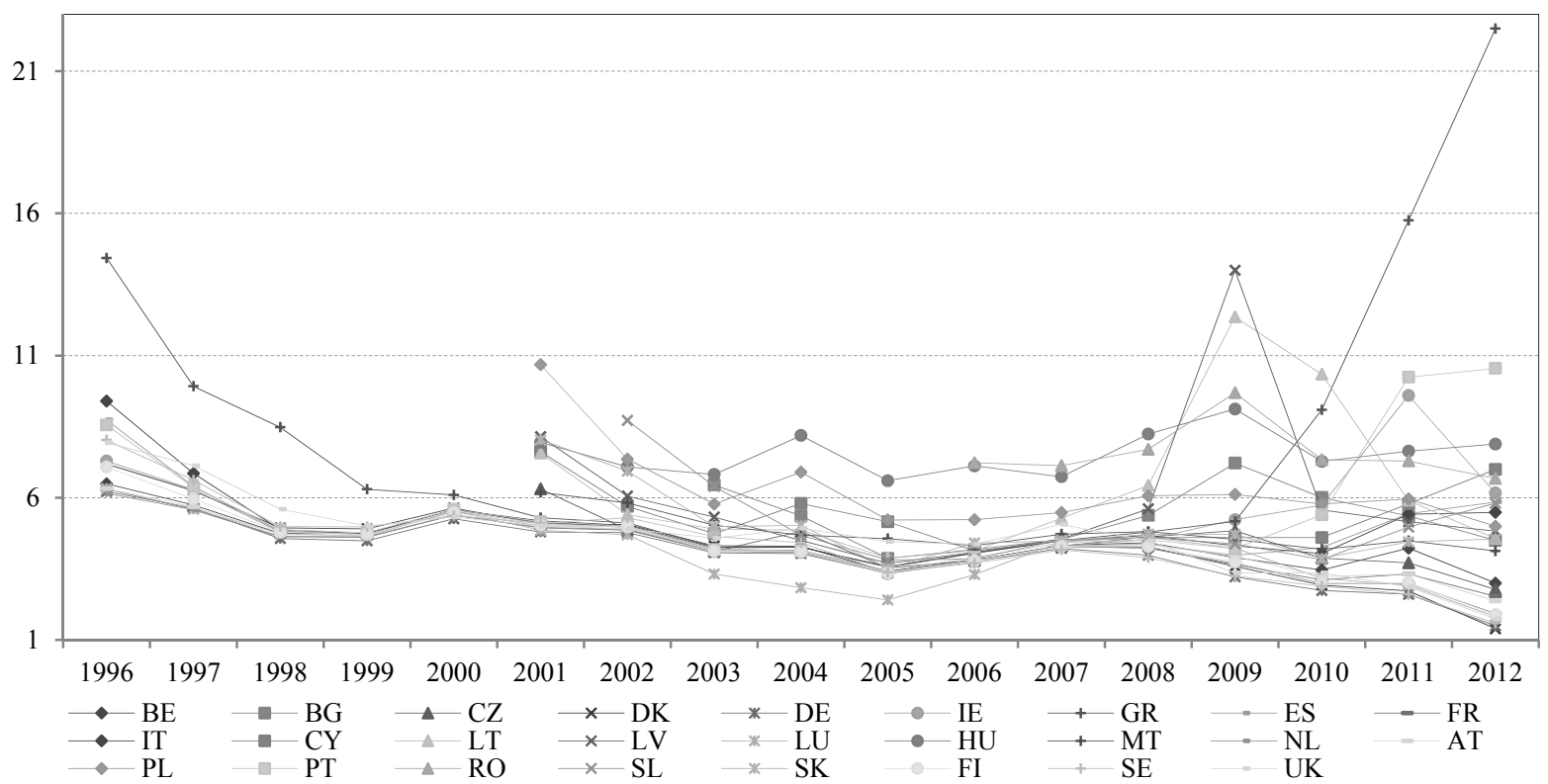

Figure 5 EMU convergence criterion bond yields, percentages per annum, 1996-2011

Source: Eurostat (2013)

Note: For more countries data are not available for more years. For Estonia, data are not available for any year in the period 1996-2012 (see the explanation above).

The indicator available for Estonia is not fully harmonized. There are no Estonian sovereign debt securities complying with the definition of long-term interest rates for convergence purposes. For Cyprus, primary market yields are reported. The same applies to Bulgaria and Romania up to December 2005, Slovenia up to October 2003 and Lithuania up to October 2007. A harmonized long-term interest rate for Luxembourg is available starting in mid-May 2010. Previously, the Luxembourg Government did not have outstanding long-term debt securities with a residual maturity of close to ten years. The yield in long-term bonds issued by a private credit institution with a residual maturity close to 10 years, which is presented for the period up to mid-May 2010, is not fully harmonized for that period (Eurostat, 2013).

In general, Figure 5 shows a downward trend in the development of the indicator until 2008. The variance of the indicator decreased until 2008 with the exception of some years in which the data started being available for other, i.e. new, member states. ${ }^{6}$ Therefore, the increase in variance was, among others,

6 Since 2001, data have been available for the Czech Republic, Cyprus, Latvia, Lithuania, Hungary, Malta, Poland and Slovakia, since 2002 for Slovenia, since 2003 for Bulgaria and since 2006 for Romania. Subsequently, a relatively higher increase in variance took place in 2001 and a modest one in 2004 and 2006. However, until 2008, the trend still indicated a decrease in the indicator. affected by the higher bond yield in new member states. However, the trend still indicated a decrease in the indicator. In 2008, an increase in bond yields took place in most of the EU countries except three northern economies, Germany, France and the Netherlands, and the UK. Subsequently, in 2009, an increase occurred in more new member states, Greece and Ireland, with the most significant increases in Lithuania (8.39) and Latvia (5.93).

Overall, most of the data for this indicator are available for the period 2001-2012. In this period, the increase was recorded in several economies, whereas the largest one was typical of Greece (17.2 p.p.). It was followed by Portugal (5.39 p.p.), Ireland (1.16 p.p.), Spain (0.73 p.p.) and Italy ( 0.3 p.p.). The remaining EU countries recorded a decline in this indicator over the period. Even though more of the new member states experienced high growth in interest rates in 2009 (especially Lithuania and Latvia) after they had been gradually declining since the beginning of the decade, since 2010 they have been lower than in 2001 in the majority of the new member states for which data were available. ${ }^{7}$ The reasons for this fact are, among others, the high values of the rates at the beginning of the decade. In addition, after the

\footnotetext{
7 This is except for Romania, where, however, data are available only since 2006 . Minor increases of 0.11 p.p. and 0.06 p.p. were subsequently recorded in 2006-2010 and 2006-2011.
} 
rise in 2009, the rates subsequently declined in 2010 in most of them except Cyprus, where no change occurred. ${ }^{8}$ In 2011, there was an adverse trend again with an annual increase in rates in many EU countries, including the new member states (except Latvia, Bulgaria, Lithuania, the Czech Republic and Romania). However, in 2012, they again declined in the majority of the EU countries. Recently, the most significant increases have again occurred in Greece, where in 2011 and 2012 the rate increased annually by more than 6 p.p. up to $22.5 \%$ in 2012 . Overall, on the one hand, there are countries in the EU with low average rates, such as Luxembourg, Germany, the three northern economies, Netherlands, France and Austria (lower than 4\%). On the other hand, the average values are relatively higher especially in the new member states and southern economies. ${ }^{9}$ However, whereas the majority of new member states have shown signs of a decrease in rates, except in the period of significant impacts of the economic crisis, the economies of Greece, Portugal and Ireland for instance have shown a trend of increase in the long term as well as in most recent years (2010-2012). In addition, in most of the recent period, the increase is also typical of Cyprus, because of the continuing problems resulting from the economic crisis. To sum up, it can be said that the downward and convergence trend in the development of long-term interest rates was again broken due to the impacts of the global economic crisis. The variance of the indicator increased significantly in 2009, decreased in 2010 and recorded growth again in 2011 and more sharply in 2012. This is the result of problems related to the unsustainable high debt levels in more countries, especially Greece, Portugal and Cyprus, leading to negative impacts on the whole euro area.

When examining the convergence of the interest rates, it is necessary to distinguish between the nominal and the real interest rate (see e.g. Mongelli, 2008). Even if the assumption of nominal interest rates' convergence in the single currency area was accepted, the real interest rates cannot be omitted. While we have experienced the convergence of nominal interest rates at the time not affected by economic crisis and the harmonization of interest rates in general, a channel of real interest rates can still work within the monetary union. Persistent inflation differentials (see Section 3.1) lead to different real interest rates, whereas higher inflation rates are associated with lower real

\footnotetext{
${ }_{9}^{8}$ For Cyprus, primary market yields are reported.

9 Average values computed of bond yields in the period 2001-2011 (in the period 2003-2011 for Bulgaria, 20062011 for Romania and 2002-2012 for Slovenia) using the available data on Eurostat (2013).
}

interest rates. If the relatively higher inflation rates result from overheating of the domestic economy, then the lower real interest rate may act pro-cyclically and the economy will experience a different development of the economic activity cycle compared with other economies, or its development will diverge from the development of other countries of the integration group. This development in the monetary union can be dangerous. The single monetary policy of the ECB would not be able to cope with this asymmetry, since it can only target the average inflation rate for the monetary union as a whole. On this assumption, it can foster economic divergence within the euro area.

The differentials in real interest rates cannot be examined in isolation. When the domestic inflation rate exceeds the average rate of the euro area, the procyclical effects arising from the common nominal interest rate may partially be compensated for by the anti-cyclical effect resulting from the rigidity of the nominal exchange rate, i.e. this economy loses competitiveness. Accordingly, while the asymmetric inflationary shock is enhanced by the common interest rates, the losses of competitiveness operate in the opposite direction. This represents the working and influence of the cost factors of real appreciation, whereas in some EU countries it is possible to confirm significant real appreciation based on the ULC as well as the CPI (see Section 4.2). Real appreciation has especially been true of the new member states, southern economies (Greece, Spain, Portugal and Italy) and Ireland or Denmark (especially in terms of REER (ULC)), while it is dependent upon the indicator of the REER (ULC, CPI) and the examined period. Even if part of the real appreciation in new member states is still attributed to the structural factors, the ECB can promote the losses of competitiveness in these countries similarly to, for example, the southern economies or Ireland.

However, according to the ECB (2004), the channel of the real interest rate in the euro area does not play a particularly significant role as an asymmetric transmission channel leading to the divergence of economic growth and inflation, with the exception of, for example, the Irish economy (European Commission, 2007). Thus, the working of this channel can be particularly dangerous to a small, open and converging economy. This is also evident from the significantly negative development in this economy, which followed the shock in the form of the recent economic crisis. Overall, the ECB (2004) argued that the natural real interest rate in the euro area as a whole has been declining. In the long run, the natural real interest rate is determined by factors such as the growth rate of productivity, demographic factors, differences in the risk premium, time preferences of consumers, etc. 


\subsection{Fiscal criteria and the importance of conver- gence in the $\mathrm{EU}$ and the euro area}

Two fiscal criteria were included in the Maastricht criteria, i.e. the government deficit and debt as a ratio to the GDP. A lack of fiscal discipline, i.e. high deficits of government (public) budgets and excessive government debts, has been typical of many EU economies, particularly the older member states. The economic crisis has further deepened these aspects. However, the trend of deterioration in the fiscal position is not a new phenomenon in developed economies. Since the 1970s, the public debt in developed economies has cumulated due to the use of fiscal policy to mitigate the cyclical downturns of the economy. However, there has not been a reduction in deficits at the time of economic expansion (Mongelli, 2008). Table 2 shows the balance of government budgets and public debts in the EU economies in 2011 and 2012. The unhealthy fiscal situation in these years is particularly evident in the economies of Greece and Ireland in both indicators, whereas in Ireland the situation started to be serious in relation to the economic crisis (since 2008). This country showed moderate deficits in 1995 and 1996 and since then surpluses were typical of this country until 2007. Besides these countries, high levels of deficit have especially been evident in Spain, Portugal and the UK as well as in Cyprus and others. Most of these countries as well as some others failed to meet the $3 \%$ of GDP criterion for many years.

Regarding the government debt, the highest levels were reached by Greece, Italy and Belgium continu- ously in the longer-term period (data have been available since the middle of the 1990s). The group may be completed with the recent addition of Portugal, where debt has been rising, and in 2011 this country surpassed Belgium. The relatively high levels of government debt with the relative lower levels of government deficits have been typical of Italy and Belgium in the longer-term period. However, after the crisis, their deficits still reached higher levels than 3\% of the GDP (Italy $-3 \%$ in 2012). Since 2000, the deficits (especially in Ireland, the UK, Spain and Finland) and debts (especially in Ireland, Portugal and Greece) increased significantly in many of the EU economies. This is related to the impacts of the global economic crisis but also to the above-mentioned longer adverse development in fiscal policy. Thereby, the macroeconomic policy affects the economic growth and the growth is negatively associated with inflation, large budget deficits and distorted foreign exchange markets (Fischer, 1993). The question arises of whether on these assumptions the monetary union is able to ensure the long-term economic growth of its countries while many of them have lost competitiveness in relation to fiscal indiscipline and other macroeconomic indicators.

As a result of the economic crisis, in 2009, no country of the EU achieved a government surplus, five countries had a deficit above 10\% of the GDP (Portugal, Spain, the UK, Ireland and Greece) and only five countries had a level under 3\% of the GDP (Sweden, Luxembourg, Estonia, Finland and Denmark). In 2010 , there were still three countries with a level of

Table 2 General government gross debt and balance of the general government budget under the excessive deficit procedure, percentage of GDP in the EU countries, 2011 and 2012

\begin{tabular}{|l|c|c|c|c|c|c|c|c|c|}
\hline Country & $\begin{array}{c}\text { Debt } \\
2011\end{array}$ & $\begin{array}{c}\text { Debt } \\
2012\end{array}$ & $\begin{array}{c}\text { Balance } \\
2011\end{array}$ & $\begin{array}{c}\text { Balance } \\
2012\end{array}$ & Country & $\begin{array}{c}\text { Debt } \\
2011\end{array}$ & $\begin{array}{c}\text { Debt } \\
2012\end{array}$ & $\begin{array}{c}\text { Balance } \\
2011\end{array}$ & $\begin{array}{c}\text { Balance } \\
2012\end{array}$ \\
\hline$E E$ & 6.2 & 10.1 & 1.2 & -0.3 & $M T$ & 70.3 & 72.1 & -2.8 & -3.3 \\
\hline$B G$ & 16.3 & 18.5 & -2.0 & -0.8 & $A T$ & 72.5 & 73.4 & -2.5 & -2.5 \\
\hline$L U$ & 18.3 & 20.8 & -0.2 & -0.8 & $H U$ & 81.4 & 79.2 & 4.3 & -1.9 \\
\hline$R O$ & 34.7 & 37.8 & -5.6 & -2.9 & $D E$ & 80.4 & 81.9 & -0.8 & 0.2 \\
\hline$S E$ & 38.4 & 38.2 & 0.2 & -0.5 & $E S$ & 69.3 & 84.2 & -9.4 & -10.6 \\
\hline$L T$ & 41.9 & 40.7 & -3.6 & -1.2 & $C Y$ & 71.1 & 85.8 & -6.3 & -6.3 \\
\hline$L V$ & 38.5 & 40.7 & -5.5 & -3.2 & $U K$ & 85.5 & 90.0 & -7.8 & -6.3 \\
\hline$C Z$ & 40.8 & 45.8 & -3.3 & -4.4 & $F R$ & 85.8 & 90.2 & -5.3 & -4.8 \\
\hline$D K$ & 46.4 & 45.8 & -1.8 & -4.0 & $B E$ & 97.8 & 99.6 & -3.7 & -3.9 \\
\hline$S K$ & 43.3 & 52.1 & -5.1 & -4.3 & $I E$ & 106.4 & 117.6 & -13.4 & -7.6 \\
\hline$F I$ & 49.0 & 53.0 & -0.8 & -1.9 & $P T$ & 108.3 & 123.6 & -4.4 & -6.4 \\
\hline$S L$ & 46.9 & 54.1 & -6.4 & -4.0 & $I T$ & 120.8 & 127.0 & -3.8 & -3.0 \\
\hline$P L$ & 56.2 & 55.6 & -5.0 & -3.9 & $G R$ & 170.3 & 156.9 & -9.5 & -10.0 \\
\hline$N L$ & 65.5 & 71.2 & -4.5 & -4.1 & & & & & \\
\hline$S O U F$ & & & & & & & & & \\
\hline
\end{tabular}

Source: Eurostat (2013)

Note: Values are arranged according to the size of the government debt from the lowest to the highest in 2012. 
deficit higher than 10\% (the UK, Greece and Ireland as much as $30.8 \%$ of the GDP). Two countries already showed a surplus (Sweden and Estonia). In 2011, the situation of deficits further improved with three countries' levels above 9\% of the GDP (Spain, Greece and Ireland) and three countries with a government surplus (Hungary, ${ }^{10}$ Estonia and Sweden). It is evident that the highest government budget deficits have recently been attained by Ireland $(13.9 \%, 30.8 \%$, $13.4 \%$ and $7.6 \%$ of the GDP in 2009-2012 annually). This is the result of the Irish banking crisis, which is connected with the global financial and economic crisis and has led to a number of financial institutions requiring government assistance. However, the declines in the level of deficit in the most recent years can be understood as a sign of improvement in the situation. In addition, as a result of the crisis, the Irish debt overtook the level of $90 \%$ in 2010 , similarly to Portugal. Therefore, in 2010 and 2011, five countries showed a government debt higher than $90 \%$ of the GDP, whereas four of them had a higher level than $100 \%$ of the GDP in 2011 (Belgium, Ireland, Portugal, Italy and Greece). In 2012, the UK and France reached the level of $90 \%$ as well (see Table 2). While in Greece the level of debt decreased annually in 2012, in other economies, such as Portugal, Spain, Cyprus and Ireland, the level further significantly increased. A sharp increase in 2012 was also typical of two new member states, i.e. Slovakia and Slovenia.

To sum up, it can be said that in spite of some necessary reductions of government deficits in most of the EU countries after the economic crisis, especially in 2010 and 2011, the deficits are still high, which further deteriorates the development of government debts. The levels of debt have been rising in many, especially older, member states, for a longer period. In general, the northern countries of the EU (for example Estonia, Sweden, Denmark, Finland, Lithuania and Latvia) have shown higher fiscal discipline from the long-term view than the southern ones (for example Spain, Portugal and Italy). This has resulted in a greater ability of the northern countries to cope with the impacts of the last economic crisis. The exception is the economy of Ireland, which has been affected by an extensive banking crisis. There were some signs of improvements in this country in terms of the deficit reduction after the year 2010. However, the impacts on the government debt have already been significant and the growing debt levels have also been typical of more countries of the EU. Moreover, there was again a large number of the EU countries in which the government deficits increased in 2012 (see Table 2). Due to the significant linkages between the integrating countries, the negative results of the economic crisis still persist, expand and spill over from one to another.

It is important to monitor the fiscal characteristics in combination with the indicators of external balance. Adverse development of fiscal characteristics in combination with adverse trends in the current account of the balance of payments (BOP) can strengthen each other. On the assumption that a country is a member of the monetary union, this can cause significant negative effects on the country itself as well as on the other members. The combination of adverse development in fiscal characteristics and adverse development in the current account of the BOP has further worsened the situation of more EU economies regarding competitiveness, especially of the euro area members.

From the long-term perspective, the most positive development in terms of the current account surpluses (percentage of GDP) has been typical of Luxembourg, three northern economies, the Netherlands and Germany since 2002. In 2010, 2011 and 2012, the most favourable values were typical of the Netherlands, Luxembourg, Germany and two northern economies Sweden and Denmark. Ireland attained a significant surplus in 2012 again after previous slight surpluses and deficits. Slovakia and Slovenia improved their current account position in 2012 and reached a surplus in comparison with the previous two years (see Figure 6). This is in conflict with the sharp increase in government debt in both countries in this year. However, the positive effects can show themselves in the future, assuming that the positive development of the external balance persists. As Figure 6 further shows, the highest values of current account deficit in the monitored years were reached by Greece, Portugal (a relatively lower level in 2012) and Cyprus, whereas Cyprus dominated that value in 2012. Two other new member states, i.e. Romania and Poland, have also reached relatively higher current account deficits from the longer-term perspective. This is also true of two other countries with adverse fiscal characteristics, i.e. Italy and Spain, but with a significant decrease in 2012, whereas in Italy the negative development has taken place since around 2006. Both these countries were in recession for the whole year of $2012 .{ }^{11}$

\footnotetext{
${ }^{10}$ However, the surplus in Hungary in 2011 is explained by the transfer of financial assets from the second pillar pension funds to the Government, which was recorded as a capital transfer to the Government, improving the government balance by 9.5 p.p. of the GDP (Eurostat, 2013).
}

\footnotetext{
${ }^{11}$ According to data from Eurostat (2013), Spain achieved quarterly drops in its real GDP from the fourth quarter and Italy from the third quarter of 2011 to the end of 2012, when the last data were available.
} 


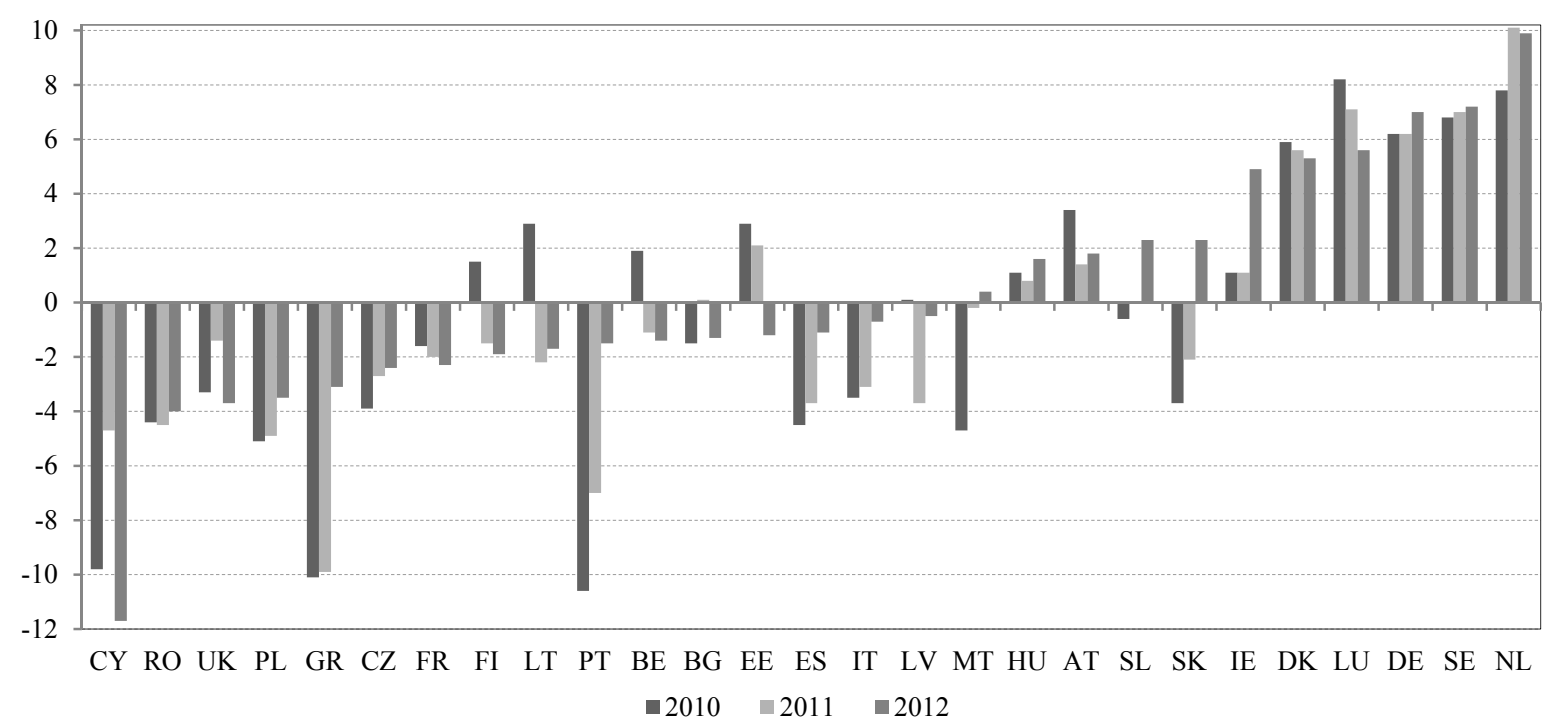

Figure 6 Current account of the balance of payments in the EU countries, percentage of GDP, in 2010, 2011 and 2012 Source: Eurostat (2013)

Note: Values are arranged according to the level in 2012 from the lowest to the highest.

Moreover, the adverse development in some countries has taken a longer time, which is connected with the losses of competitiveness. This is typical of Portugal, Greece or Spain. The adverse trend in terms of current account deficits has mostly persisted in all the new member states, with some exceptions in Slovenia. However, in some of them, the deficits have diminished significantly or turned into surpluses in the most recent period, particularly in Hungary, Slovenia, Slovakia and Malta. The positive changes in trends were initially caused by decreases in foreign trade with more significant decreases in imports due to the recession in terms of the economic crisis. They could still continue but the changes in competitiveness could play a role as well. Competitiveness affects the possibilities of a country's foreign trade and the whole current account of the BOP. All this is reflected in the development of the real exchange rates (see Section 4.2).

Regarding the new member states, the fiscal situation in combination with a single currency seems to have had the most adverse effects on the economy of Cyprus, with high and growing government deficit and debt since 2009. In addition, the current account deficits of BOP have continually persisted in this economy since the mid-1990s (with one exception in 1998), and have further been growing sharply due to the economic crisis. On the other hand, this economy is small, so the impacts on the rest of the euro area should not be as extensive as the impacts resulting from similar problems of the above-mentioned economies of the older member states. Potential problems could arise in Poland, which is also the economy with persisting and often growing deficits of the current account since 1996 as well as worsening fiscal discipline. This economy is the only one in the EU that did not record a decline in the real GDP due to the crisis in 2009, which, on the other hand, had negative effects on the fiscal development. However, this economy may still use the exchange rate change to defend itself against problems.

It is necessary to point out the deeper aspects of fiscal policy in a monetary union and after the interest and exchange rates the possible working of an additional asymmetric transmission channel. Discretionary fiscal policy should be neutral over the cyclical development and automatic stabilizers should operate in an anti-cyclical way, i.e. they should reduce the cyclical fluctuations of the economy. However, if the government in the economy is unable to achieve a sound fiscal situation at the time of an economic boom (i.e. a balance or surplus of the government budget), it may not be able to use these tools effectively and to maintain the deficit of $3 \%$ of the GDP at the time of the cyclical downturn. The pro-cyclical fiscal policies were typical of some EU countries in the 1970s and 1980s. Transition to the EMU and the associated obligation of fiscal discipline resulting from the obligation to fulfil the Maastricht criteria before joining the euro also resulted in a pro-cyclical effect of fiscal policy in the recession phase. Shortly after the establishment of the euro area, a loosening of the fiscal policy in some countries at the time of recovery again led to pro-cyclical behaviour, but in good times. Moreover, the subsequent cyclical decline led to the accumulation of excessive budget deficits in the 
period 2003-2005, which required corrective action at the time of the cyclical downturn. This again represents the pro-cyclical approach. The significant increase in deficits in 2009 and 2010 had already been a serious problem and a further pro-cyclical approach in connection with the need for significant savings is simply not feasible. The limitation of economic growth in some EU economies has arisen and the impact on the other EU countries has already been made evident due to the existence of significant links between them. Assuming the euro area participation in connection with adverse fiscal developments of economies, a lack of competitiveness and other factors, then significantly negative impacts on all the member states of the monetary union are likely to occur (Mongelli, 2008).

\subsection{Impacts of the Maastricht convergence criteria on economic growth}

A stable macroeconomic environment is a necessary but not sufficient condition for economic growth. High or volatile inflation and budget deficits reduce economic growth by reducing investment and productivity growth. High inflation is not compatible with sustainable growth in the long run (Fischer, 1993). Therefore, the adverse development of indicators covered by the Maastricht criteria can ultimately undermine economic growth. Impacts on economic growth are also connected with the possible transmission channels that can exist in a monetary union. According to the economic theory, a positive correlation between real interest rates and economic growth should exist across different countries. However, in a monetary union such as the euro area, a negative correlation between real interest rate differentials and growth differentials of products, at least over business cycle frequencies, can be expected. The single monetary policy can have pro-cyclical effects leading to faster growth in economies with higher inflation rates (Mongelli, 2008). Following the losses of competitiveness associated with the effects of cost factors of real appreciation, it also leads to negative impacts on economic growth. The significant appreciation of the REER indicators in the longer-term period has been the case for many EU countries, especially the southern economies, Ireland and the new member states. The above-examined negative impacts of fiscal indiscipline in many EU countries on economic growth can also result from the pro-cyclical fiscal policies. This is another transmission channel that can exist in connection with the monetary union. However, pro-cyclical fiscal policies had already been implemented in some EU countries in the 1970s and 1980s (Mongelli, 2008).

The impacts of nominal convergence, as defined by the Maastricht criteria, on macroeconomic conver- gence in the other concepts cannot be left unmentioned. The possible impacts on real and nominal convergence in their narrow conceptions, i.e. on parallel growth of the GDP per capita and the CPL in countries with a lower initial level, can take place in particular by simultaneous fulfilment of the price and exchange rate criteria. During the CPL development, the B-S effect can play a role, which leads to higher inflation rates and/or nominal exchange rate appreciation that are bot reflected in the real exchange rate appreciation. These countries are especially the new member states as well as some less-developed older members. The situation after joining the euro area is potentially more dangerous to these countries. Then, the exchange rate channel of catching up with the CPL is completely excluded and the price channel is limited by the monetary policy of the ECB. It may ultimately limit the growth of the GDP and the catching up of these countries with the developed ones. The resulting effect still depends on the possible working of the above-mentioned transmission channels. However, they particularly depend on many other factors affecting the costs and benefits of the membership of the monetary union, which ultimately affect the economic growth. In these terms, the OCA theory can provide a guide to whether and when it is appropriate to join the monetary union. In the EU, this question remains to be solved by several new member states.

In summary, it can be said that the impacts of convergence, in terms of Maastricht criteria fulfilment, on economic growth are mainly due to their affect on the stability of the macroeconomic environment as well as the working of several pro-cyclical and anti-cyclical transmission channels. In addition, the impacts on convergence in terms of catching up can take place with ultimate impacts on economic growth, whereas the catching-up countries are especially the new member states regarding the date of joining the euro area. This means that these aspects need to be taken into account in their decision making because Maastricht criteria fulfilment and joining the euro area can ultimately affect their economic growth.

\section{Conclusion}

This paper focused on the detection of nominal convergence of the EU economies using the indicators of convergence, which stem from the basic framework provided by the Maastricht criteria. Thereby, the classification of convergence criteria according to the Maastricht criteria was used as a starting point for the analysis, whereas alternative indicators were included and broader relations of convergence indicators were examined as well. In summary, convergence of the inflation and interest rates, development of the real exchange rates as well as development of the fiscal 
indicators in terms of government deficit and debt were analysed in the EU countries in a broader meaning. The potential impacts on economic growth resulting from the examined areas of convergence were subsequently indicated and summarized. These impacts were divided in relation to the membership of the euro area.

Between the period 1997-2003 and the period 2004-2010, the average HICP inflation rates declined, especially in the new member states. In the second period, however, a period of global economic crisis took place when a significant decline in inflation rates occurred in 2009. The standard deviation of the HICP inflation rate in the EU and the euro area has most often shown a downward trend, which is a sign of convergence. Subsequently, it significantly increased in 2007 and 2008, which are the years immediately before the significant impacts of the economic crisis. In 2009, the standard deviation decreased in the EU as well as in the euro area because of the recession and low inflation rates in all the countries of the EU. Overall, inflation in many EU countries has shown significant persistence over a long period. Persistent inflation differentials are a reflection of structural rigidities. However, differences in inflation rates will persist if there are, among many other factors, differences in the price levels between economies. Differences in inflation rates lead to a loss of competitiveness in economies with high inflation rates, which raises the need for mechanisms of adaptation in a monetary union.

Real exchange rates are both a nominal and a real convergence indicator, so they also reflect many characteristics of development of other indicators, which were examined in this paper. It is necessary to distinguish between structural factors and cost factors of real appreciation. The structural factors of real appreciation should not lead to adverse effects on competitiveness if referring to a temporary development in transition economies with a lower initial level of the CPL. The working of the B-S effect is connected with this development and it can still play a role, especially in new member states. However, all new member states achieved significant appreciation of the REER based on the CPI as well as on the ULC in the period 1995-2011, whereas these indicators reflect changes in cost and price competitiveness. Real appreciation has also been typical of some older member states, especially four southern ones and Ireland. Conversely, some more advanced EU economies, such as Germany, Austria, Finland, Belgium, France and Sweden, achieved real depreciation in the period 1995-2011 in REER indicators. This reflects the increase in competitiveness in these countries and losses in competitiveness in the southern ones, Ireland and others, whereas in the new member states the structural factors of real appreciation can still play a role. Therefore, the losses of competitiveness could be more moderate in these countries. Recently, some older as well as new member states have experienced real depreciation or the real appreciation has been reduced, which can still reflect the negative impacts of the economic crisis.

The variation coefficients and standard deviations of the examined interest rates on loans to households and non-financial corporations (short and long term) decreased in the period 1996-2012 in the euro area as well as in the EU. This reflects their convergence and the increase in the financial market integration in the EU and the euro area. As a result of the financial crisis, growth occurred in the coefficients of variation and standard deviations in the EU and the euro area in the above-monitored interest rates between 2008 and 2009. The long-term government bond yields and their variance recorded a downward trend until 2008. The yields increased significantly in several economies in 2009. The variance of the indicator increased significantly in 2009 too, decreased in 2010 and again recorded growth in 2011 and 2012 because of the resulting problems related to the unsustainable high debt levels in several EU countries, especially Greece. Adverse development of fiscal characteristics, especially in the older member states, has taken place for a long time and deteriorated as a result of the recent economic crisis. The combination of unfavourable developments in the fiscal indicators with the deficits of the current account of BOP has further worsened the situation in several EU economies in terms of competitiveness.

To sum up, the external shock in terms of the recent economic crisis has affected the convergence of inflation and interest rates as well as the whole development of the real exchange rates. The interest rates have diverged. The inflation rates diverged before the crisis and their convergence at the time of the crisis was caused by the recession, which led to lower inflation rates in all the EU economies. Some recent trends of real depreciation can be related to the lack of growth and adverse economic development in general due to the crisis as well. The crisis has also further worsened the fiscal discipline in the EU countries. The negative effects have spilled over among countries because of the significant interrelations among them. On these assumptions, it is very doubtful whether the monetary union will be able to ensure the long-term economic growth of its countries while many of them have lost competitiveness in relation to fiscal indiscipline and adverse development of other macroeconomic indicators, including the indicators of external balance. Thereby, the stability and favourable development of macroeconomic indicators included in the 
Maastricht criteria represent only the necessary but not sufficient conditions of economic growth.

Moreover, in the context of the Maastricht convergence criteria, some asymmetric transmission channels can work, which can also influence the economic growth in the euro area. Within the monetary union, the pro-cyclical real interest rate channel can act, which may be offset by the anti-cyclical effects arising from the nominal exchange rate rigidity. The procyclical real interest rate channel might have played a role in the Irish economy. The second channel leads to the appreciation of the REER and a decrease in the competitiveness of the economy. As mentioned above, this development is typical of many EU countries. In addition, the third channel lies in the pro-cyclical use of fiscal policy in the EU economies, which generally, and especially in the monetary union, leads to negative impacts on economic growth and can significantly jeopardize its existence and functioning. Regarding the long-term development of fiscal discipline in most of the EU countries, which has further been enhanced by the impacts of the economic crisis, these effects can be significantly negative.

Finally, Maastricht criteria fulfilment and membership of the euro area can have impacts on catching up, i.e. faster simultaneous growth of the real GDP per capita and the CPL in the new member states, and eventually in some less-developed countries of the EU-15. After the euro area entry, the exchange rate channel of catching up with the CPL is completely excluded and the price channel is limited by the monetary policy of the ECB. This may ultimately limit the growth of the GDP and the catching up of these countries with the developed ones, also depending on the working of the above-mentioned transmission channel. From that point of view, those countries considering euro area access should carefully assess the costs and benefits of their membership according to the optimum currency area theory because it can ultimately affect their economic growth.

\section{Acknowledgements}

This paper has been created within the SGS research project SP2011/121 of VSB-TU Ostrava.

\section{References}

BALASSA, B. (1964). The purchasing-power parity doctrine: A Reappraisal. The Journal of Political Economy 72(6): 584-596.

http://dx.doi.org/10.1086/258965

BARRO, R.J., SALA-I-MARTIN, X. (2004). Economic Growth. 2nd Edition. Massachusetts: Massachusetts Institute of Technology Press.
CINCIBUCH, M., VAVRA, D. (2000). Towards the European monetary union: A need for exchange rate flexibility? Transition Economics Series, No. 17. Wien: Institut für Höhere Studien.

FISCHER, S. (1993). The role of macroeconomic factors in growth. NBER Working Paper Series, No. 4565. Cambridge: National Bureau of Economic Research.

FRAIT, J., KOMÁREK, L. (2001). Na cestě do EU: nominální a reálná konvergence $\mathrm{v}$ tranzitivních ekonomikách. Finance a úvěr 51(6): 314-330.

KOWALSKI, P.A. (2003). Nominal and real convergence in alternative exchange rate regimes in transition countries: implications for the EMU Accession. Center for Social and Economic Research (CASE) Network Studies and Analysis, No. 270. Warsaw: CASE.

MONGELLI, F.P. (2008). European economic and monetary integration and the optimum currency area theory. Economic Papers, No. 302. Brussels: Directorate-General for Economic and Financial Affairs. European Commission.

SAMUELSON, P.A. (1964). Theoretical notes on trade problems. The Review of Economics and Statistics 64(2): 145-154.

ŠIKULOVÁ, I. (2006). Konvergencia v procese európskej menovej integrácie. Bratislava: Ekonomický ústav Slovenskej akadémie vied.

The treaty of Lisbon. Consolidated version of the treaty on the functioning of the European Union. (2007). Official Journal of the European Union 50 (C 306). Available at: <http://eur-lex.uropa.eu/exUri Serv/exUriServ.do?uri=OJ:C:2007:306:FULL:N:PDF $>$.

VINTROVÁ, R., ŽĎÁREK, V. (2007). Vztah reálné a nominální konvergence $\mathrm{v}$ ČR a nových členských zemích EU. Working Paper CES VŠEM, No. 8/2007. Praha: CES VŠEM.

ŽĎÁREK, V. (2006). Nominální konvergence v České republice - vybrané aspekty a implikace. Working Paper CES VŠEM, No. 6/2006. Praha: CES: VŠEM.

\section{Additional sources}

BENČÍK, M., HAJNOVIČ, F. et al. (2005). Odhad Balassa-Samuelsonovho efektu $v$ ekonomike SR. Výskumná štúdia. Odbor výskumu NBS. [Online]. Available at: <http://www.nbs.sk/_img/Documents/ PUBLIK/05_KOL2.PDF>.

ECB (2004). The Monetary Policy of the ECB. [Online]. Available at: <http://www.ecb.int/pub/pdf/ other/monetarypolicy2004en.pdf $>$. 
EUROPEAN COMMISSION (2007). The EU Economy 2006 Review: Adjustment Dynamics in the Euro area. Directorate-General for Economic and Financial. Accessed 25. 03. 2007. Available at: $<\mathrm{http} / /$ ec.europa.eu/economy_finance/een/005/article _4325_en.htm>.

EUROSTAT (2013). Statistics Database 2012. [Online]. Available at: <http://epp.eurostat.ec.euro pa.eu/portal/page/portal/statistics/search database $>$.

Treaty of Lisbon amending the Treaty on European Union and the Treaty establishing the European Community, signed at Lisbon (2007). Official Journal of the European Union 50(C 306). Available at: $<$ http://eur-lex.europa.eu/JOHtml.do?uri=OJ:C:2007: 306:SOM:EN:HTML>. 